\title{
Recovery Process of Li, Al and Si from Lepidolite by Leaching with HF
}

\author{
Gustavo D. Rosales, Eliana G. Pinna, Daniela S. Suarez and Mario H. Rodriguez * \\ Laboratorio de Metalurgia Extractiva y Síntesis de Materiales (MESiMat), Facultad de Ciencias Exactas y \\ Naturales, Universidad Nacional de Cuyo, Mendoza 5500, Argentina; gd_rosales@hotmail.com (G.D.R.); \\ guadapinna@yahoo.com.ar (E.G.P.); martu112001@hotmail.com (D.S.S.) \\ * Correspondence: mrodriguez@uncu.edu.ar; Tel.:+54-9261-337-9329
}

Academic Editor: William Skinner

Received: 5 January 2017; Accepted: 1 March 2017; Published: 3 March 2017

\begin{abstract}
This work describes the development of a new process for the recovery of $\mathrm{Li}, \mathrm{Al}$ and $\mathrm{Si}$ along with the proposal of a flow sheet for the precipitation of those metals. The developed process is comprised of lepidolite acid digestion with hydrofluoric acid, and the subsequent precipitation of the metals present in the leach liquor. The leaching operational parameters studied were: reaction time, temperature and HF concentration. The experimental results indicate that the optimal conditions to achieve a $\mathrm{Li}$ extraction higher than $90 \%$ were: solid-liquid ratio, $1.82 \%(w / v)$; temperature, $123{ }^{\circ} \mathrm{C}$; HF concentration, 7\% (v/v); stirring speed, $330 \mathrm{rpm}$; and reaction time, $120 \mathrm{~min}$. Al and Si can be recovered as $\mathrm{Na}_{3} \mathrm{AlF}_{6}$ and $\mathrm{K}_{2} \mathrm{SiF}_{6}$. LiF was separated from the leach liquor during water evaporation, with recovery values of $92 \%$.
\end{abstract}

Keywords: lithium; aluminum; silicon; extraction; hydrofluoric acid

\section{Introduction}

Fluorides and fluorinated materials appear in various aspects of modern life. The strategic role of fluoride materials involves diverse research fields and applications in areas such as energy production, microelectronics and photonics, catalysis, pigments, textiles, cosmetics, plastics, domestic wares, automotive technology and the construction industry.

One of the most commonly used lithium salts is LiF, which is utilized as a flux in the ceramics and glass industries, as well as in light metals welding [1,2]. It is especially used in the manufacture of optical components for analysis equipments (IR and UV spectroscopies). Also, it has recently been used in the fabrication of new cathodes for lithium-ion batteries, in the LiF-Fe ones [3]. A potentially important use of $\mathrm{LiF}$ is represented by atomic fusion, where it would be employed as a source of ${ }^{6} \mathrm{Li}$ isotopes $[4,5]$.

The fluorometalates of $\mathrm{K}$, and particularly fluorosilicates, have applications in the field of $\mathrm{Al}$ brazing. Firstly, the corresponding reaction gives rise to the formation of elemental Si and $\mathrm{K}$ fluoroaluminate, which act as a fluxing agent. The elements formed combine and alloy with $\mathrm{Al}$, diffusing through the base material so as to reach the corresponding eutectics mixtures, thereby locally lowering the melting point of the $\mathrm{Al}$ and thus acting as a metal fillet or clad, which forms the joint [6].

Synthetic cryolite is a very important fluoroaluminate regarding to its industrial applications. Probably its most important and best-known application is in the production and refining of aluminum in combination with other fluorides, the so-called Hall-Heroult process [7]. Cryolite is also employed in grinding applications as an abrasive aid in the polymeric matrix of phenolics resins [4]. Other uses, dealing with lower volumes, include solid lubricant for brakes in heavy-duty applications, and in the production of welding agents, pyrotechnics and metal surface treatments. 
Lepidolite $\left(\mathrm{KLiAl}_{2} \mathrm{Si}_{3} \mathrm{O}_{10}(\mathrm{OH}, \mathrm{F})_{3}\right)$ is a mica with a complex and variable formula. Its $\mathrm{Li}$ concentration ranges from $1.39 \%\left(3.0 \% \mathrm{Li}_{2} \mathrm{O}\right)$ to a theoretical maximum of $3.58 \% \mathrm{Li}\left(7.7 \% \mathrm{Li}_{2} \mathrm{O}\right)$. The major commercial deposits of lepidolite are in: Bikita, Zimbabwe; Bernie Lake, Manitoba, Canada; Karibib, Namibia; and Mina Gerais, Brazil [1]. In Argentina, the main deposits of lepidolite are found in the San Luis, Salta and Catamarca provinces $[8,9]$.

The most significant processes for the extraction of Li from lepidolite are the "sulfate acid" and "lime" methods. Acid digestion is carried out with concentrated sulphuric acid at temperatures higher than $250{ }^{\circ} \mathrm{C}$, whereas the lime method is carried out with $\mathrm{CaCO}_{3}$ at $1040{ }^{\circ} \mathrm{C}$. The products obtained through these methods are $\mathrm{Li}_{2} \mathrm{CO}_{3}$ and $\mathrm{LiOH}$, respectively [1,2].

Relevant findings about the dissolution of lepidolite with a combination of both pyro and hydrometallurgical routes have been published. In such processes, lepidolite is firstly calcined together with $\mathrm{Na}_{2} \mathrm{SO}_{4}, \mathrm{~K}_{2} \mathrm{SO}_{4}, \mathrm{FeSO}_{4}$ or $\mathrm{FeS}$, at temperatures higher than $800{ }^{\circ} \mathrm{C}$. Then, the obtained mixture is leached with water [10-14]. In the whole process mentioned before, the only valuable metal recovered is $\mathrm{Li}$. $\mathrm{Al}$ and $\mathrm{Si}$ are lost with the waste generated during the Li recovery process.

The aim of this paper is to describe a process to recover $\mathrm{Li}, \mathrm{Si}$ and $\mathrm{Al}$ from lepidolite and to highlight the controlling parameters of the process, including the best operational conditions.

\section{Materials and Methods}

The leaching agent was HF $(40 \% w / w)$, with analytical grade. The reagents used for the recovery assays were $\mathrm{KOH}$ and $\mathrm{NaOH}$, both of analytical grades. The employed mineral was lepidolite, extracted from the mine "Las Cuevas", located in the department of San Martín, San Luis, Argentina. The ore was concentrated by hand sorting, then grounded in a ring mill and sieved to a particle size of $<45 \mu \mathrm{m}$.

Characterization of the ore and products was performed by X-ray fluorescence (XRF) on a Philips PW 1400 instrument (Philips, Amsterdam, The Netherlands) and by X-ray diffraction (XRD) in a Rigaku D-Max III C diffractometer (Rigaku, Osaka, Japan), operated at $35 \mathrm{kV}$ and $30 \mathrm{~mA}$. The K $\alpha$ radiation of $\mathrm{Cu}$ and the filter of $\mathrm{Ni}, \lambda=0.15418 \mathrm{~nm}$ were used. Morphological analysis was done by scanning electron microscopy (SEM), in an equipment LEO 1450 VP (Zeiss, Jena, Germany) which was equipped with an EDAX Genesis 2000 X-ray dispersive spectrometer (EDAX, Mahwah, NJ, USA), used to determine the semi-quantitative composition of the residues obtained through the leaching of the minerals by electron probe microanalysis (EPMA).

Determination of lithium content in the ore was performed by atomic absorption spectroscopy (AAS) using a Varian SpectrAA 55 spectrometer (Palo Alto, Santa Clara, CA, USA) with a hollow-cathode lamp (analytical error 1.5\%). Previously, the sample (lepidolite) was dissolved using a concentrated mixture of sulfuric acid and hydrofluoric acid, according to the method of Brumbaugh and Fanus, 1954 [15]. The bulk composition of the ore is shown in Table 1, determined by AAS (Li and $\mathrm{Na}$ ) and $\mathrm{XRF}$ ( $\mathrm{Si}, \mathrm{Al}, \mathrm{Fe}, \mathrm{Ca}, \mathrm{Mg}, \mathrm{K}$ and Ti). The results of the characterization of the ore by XRD are shown in Figure 1.

Table 1. The bulk composition of the ore by AAS and XRF.

\begin{tabular}{cc}
\hline Component & \% w/w \\
\hline $\mathrm{SiO}_{2}$ & 50.78 \\
$\mathrm{Al}_{2} \mathrm{O}_{3}$ & 26.93 \\
$\mathrm{Fe}$ & 0.13 \\
$\mathrm{Ca}$ & 0.14 \\
$\mathrm{Mn}$ & 0.24 \\
$\mathrm{~K}$ & 6.5 \\
$\mathrm{Na}$ & 1.25 \\
$\mathrm{Li}$ & 2.00 \\
Others & 5.87 \\
\hline
\end{tabular}




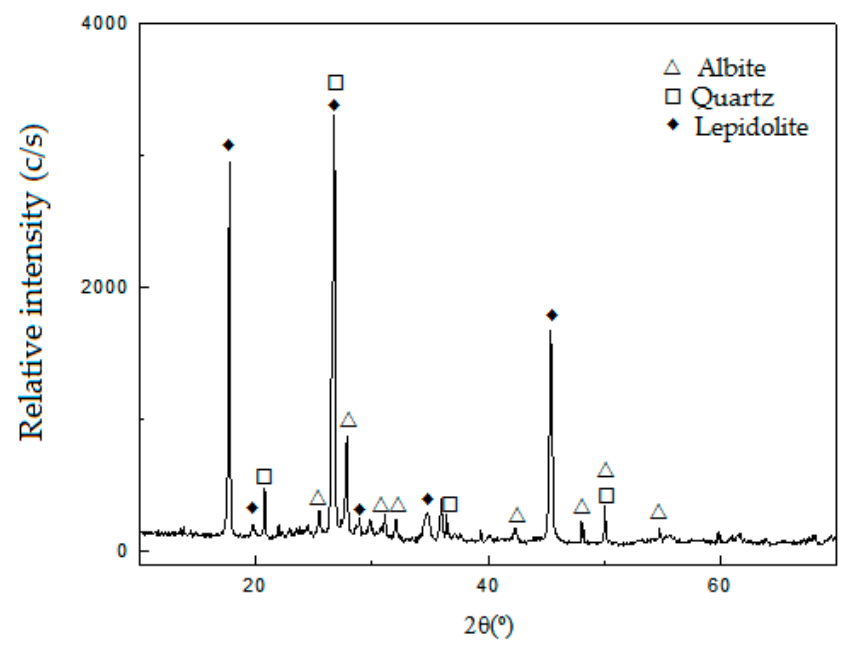

Figure 1. XRD pattern of the lepidolite concentrate.

The XRD patterns in Figure 1 show that the sample is mainly composed of lepidolite (ICDD 01-085-0398), with the presence of albite (ICDD 96-900-1631) and quartz (JCPDS 33-1161) as gangue.

\subsection{Experimental Equipment and Procedure}

\subsubsection{Leaching Assays}

The experimental tests were performed in a steel closed vessel of $500 \mathrm{~mL}$ coated with Teflon and equipped with magnetic stirring and temperature control systems.

For each test, a mass of the ore and a volume of distilled water were placed into the reactor. The mixture was subsequently heated in an oil bath, with stirring until the final work temperature was reached. Once the desired temperature was achieved, an appropriate amount of HF was added to the mixture, so as to obtain different acid concentrations. From that moment, the reaction time was calculated. Once the experiment was finished, the solid was filtered, dried at $75^{\circ} \mathrm{C}$, and then weighed.

$\mathrm{Li}$ was analyzed by atomic absorption to calculate the extraction percentage in all the experiments by the following equation:

$$
X=\frac{\mathrm{Li}_{\mathrm{s}}}{\mathrm{Li}_{\mathrm{m}}} \times 100 \%
$$

where: $\mathrm{Li}_{\mathrm{m}}$ is the initial amount of lithium in the mineral and $\mathrm{Li}_{\mathrm{s}}$ is the amount of the element in the leach liquor $[16,17]$.

The experimental study of this work was performed by univariate analysis. In order to evaluate the experimental error, each test was replicated three times. The average extraction efficiency and standard deviation were calculated for each parameter studied.

The operational studied parameters were: temperature, reaction time and HF concentration. The following parameters were kept constant: particle size, $<45 \mu \mathrm{m}$; solid-liquid ratio, $1.82 \%(w / v)$; and stirring speed, $330 \mathrm{rpm}$.

\subsubsection{Recovery Assays}

The residual $\mathrm{Si}$ and $\mathrm{Al}$ in the liquor obtained after the leaching of the mineral were removed as the compounds $\mathrm{K}_{2} \mathrm{SiF}_{6}$ and $\mathrm{Na}_{3} \mathrm{AlF}_{6}$, by using $\mathrm{KOH}$ and $\mathrm{NaOH}$, respectively. The reactions proposed for obtaining these compounds are the following [16-18]:

$$
\begin{gathered}
2 \mathrm{KOH}_{(\mathrm{aq})}+\mathrm{H}_{2} \mathrm{SiF}_{6(\mathrm{aq})} \rightarrow \mathrm{K}_{2} \mathrm{SiF}_{6(\mathrm{~s})}+2 \mathrm{H}_{2} \mathrm{O} \\
3 \mathrm{NaOH}_{(\mathrm{aq})}+\mathrm{H}_{3} \mathrm{AlF}_{6(\mathrm{aq})} \rightarrow \mathrm{Na}_{3} \mathrm{AlF}_{6(\mathrm{~s})}+3 \mathrm{H}_{2} \mathrm{O}
\end{gathered}
$$


The recovery of $\mathrm{Li}$ from the resulting solution after the precipitation of $\mathrm{Al}$ and $\mathrm{Si}$ can be carried out by one of the many known methods. In this case, lithium was precipitated as LiF, evaporating the solutions above the solubility product constant (Ksp) of $\operatorname{LiF}[16,17,19-23]$. The recovery efficiency of each element was calculated by gravimetric analysis.

In Figure 2 it is presented the process flow sheet for $\mathrm{Li}, \mathrm{Si}$ and $\mathrm{Al}$ recovery.

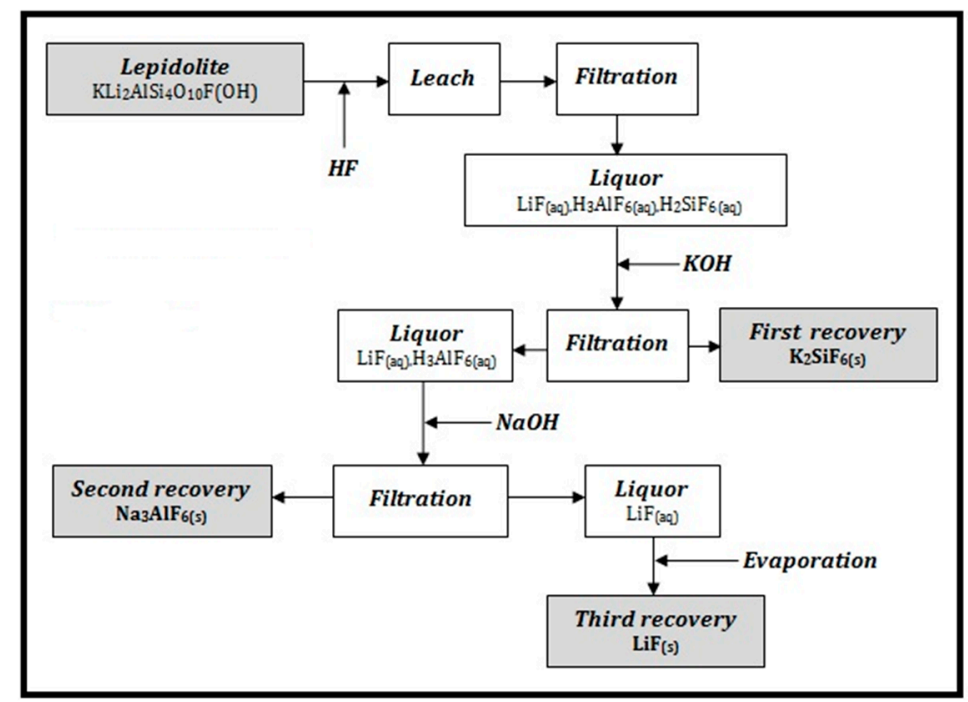

Figure 2. Generalized process flow sheet for $\mathrm{Li}$, Si and $\mathrm{Al}$ recovery from lepidolite.

\section{Results}

\subsection{Leaching of Li from Lepidolite}

The lepidolite dissolution with HF can be represented by the following reaction [16-18]:

$$
\mathrm{KLi}_{2} \mathrm{AlSi}_{4} \mathrm{O}_{10} \mathrm{~F}(\mathrm{OH})_{(\mathrm{s})}+32 \mathrm{HF}_{(\mathrm{aq})} \rightarrow 2 \mathrm{LiF}_{(\mathrm{aq})}+\mathrm{H}_{3} \mathrm{AlF}_{6(\mathrm{aq})}+4 \mathrm{H}_{2} \mathrm{SiF}_{6(\mathrm{aq})}+\mathrm{KF}_{(\mathrm{aq})}+11 \mathrm{H}_{2} \mathrm{O}
$$

\subsubsection{Effect of Temperature}

In order to investigate the effect of the leaching temperature on the Li extraction, a series of leaching experiments were performed from 75 to $220^{\circ} \mathrm{C}$. Conditions of the leaching process were as follows: solid-liquid ratio, $1.82 \%(w / v)$; HF concentration, $7 \%(v / v)$; stirring speed, $330 \mathrm{rpm}$; and reaction time, $120 \mathrm{~min}$. The results are presented in Figure 3 from which it can be appreciated from the error bars that the largest standard deviation in the experimental data is about $\pm 2.5 \%$.

Figure 3 illustrates that the reaction temperature has an obvious effect on the leaching process. The extraction efficiency increases significantly when the leaching temperature is increased from 75 to $123{ }^{\circ} \mathrm{C}$. This coincides with the results of Rosales et al. (2014 and 2016), who determined that the dissolution of lithium aluminosilicates ( $\beta$-spodumene) with HF is strongly dependent on the temperature $[17,18]$. The extraction efficiency was $90 \%$ when the reaction temperature was $123{ }^{\circ} \mathrm{C}$. However, a further increase of the temperature did not result in a clear increase of the extraction efficiency (92\%). The optimum temperature was chosen to be $123^{\circ} \mathrm{C}$ for the economic and industrial applications. 


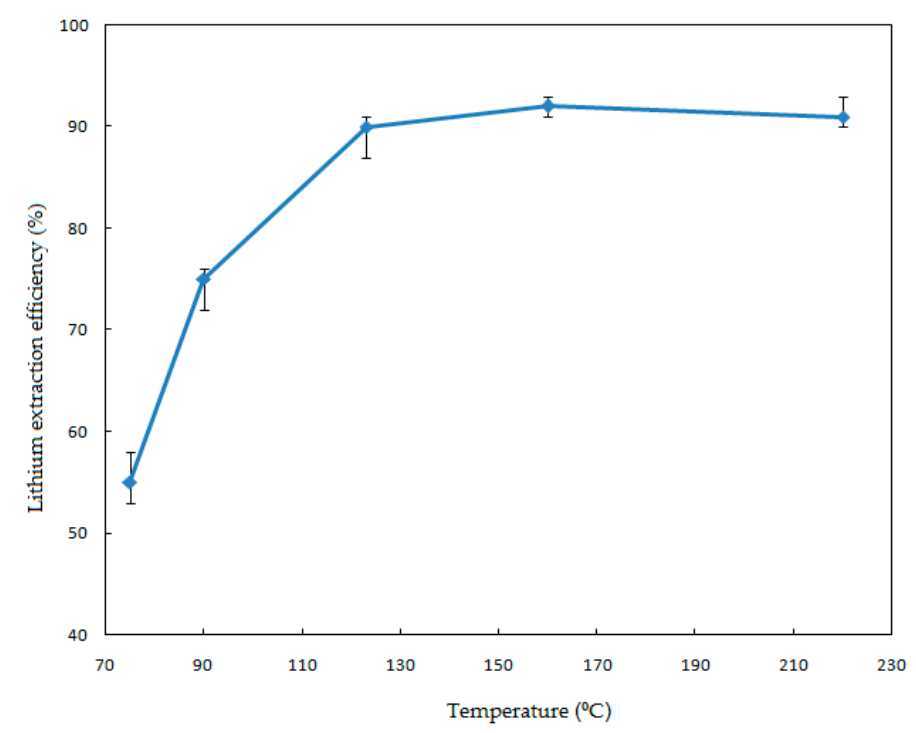

Figure 3. Effect of the temperature on the Li extraction efficiency.

\subsubsection{Effect of Reaction Time}

To study the effect of the reaction time on the $\mathrm{Li}$ extraction, experiments were conducted at conditions of solid-liquid ratio, $1.82 \%(w / v)$; HF concentration, $7 \%(v / v)$; temperature, $123{ }^{\circ} \mathrm{C}$; and stirring speed, $330 \mathrm{rpm}$.

The results are plotted in Figure 4, which shows that leaching time has a remarkable effect on the dissolution of the mineral. As the time increased from 10 to $240 \mathrm{~min}$, the lithium extraction efficiency increased from $37 \%$ to $95 \%$, due to the reaction time favoring the contact between the leaching agent and the mineral, improving the extraction efficiency. As the reaction time increased up to $120 \mathrm{~min}$, the extraction percentage of Li remained almost constant. Statistical analysis of the results indicates that there is a standard deviation of $1.6 \%$.

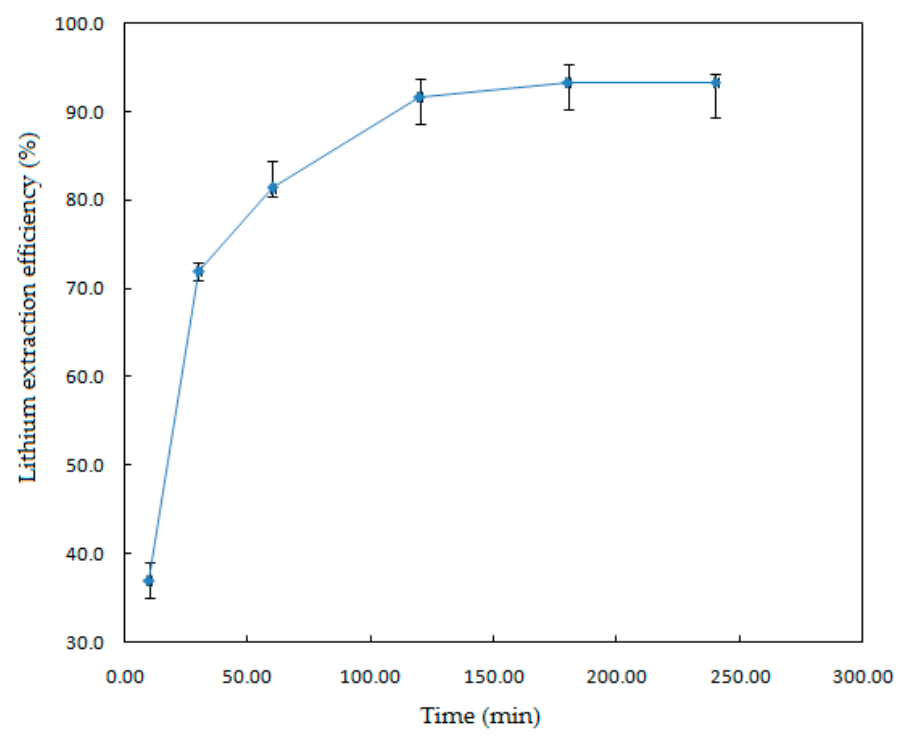

Figure 4. Effect of reaction time on the Li extraction efficiency.

\subsubsection{Effect of HF Concentration}

In order to investigate the effect of the HF concentration on the Li extraction, a series of leaching experiments were performed ranging from $7 \%$ to $20 \%(v / v)$ of HF. The conditions of the leaching 
process were as follows: solid-liquid ratio, $1.82 \%(w / v)$; stirring speed, $330 \mathrm{rpm}$; temperature, $123^{\circ} \mathrm{C}$; and reaction time, $60 \mathrm{~min}$. The results are plotted in Figure 5.

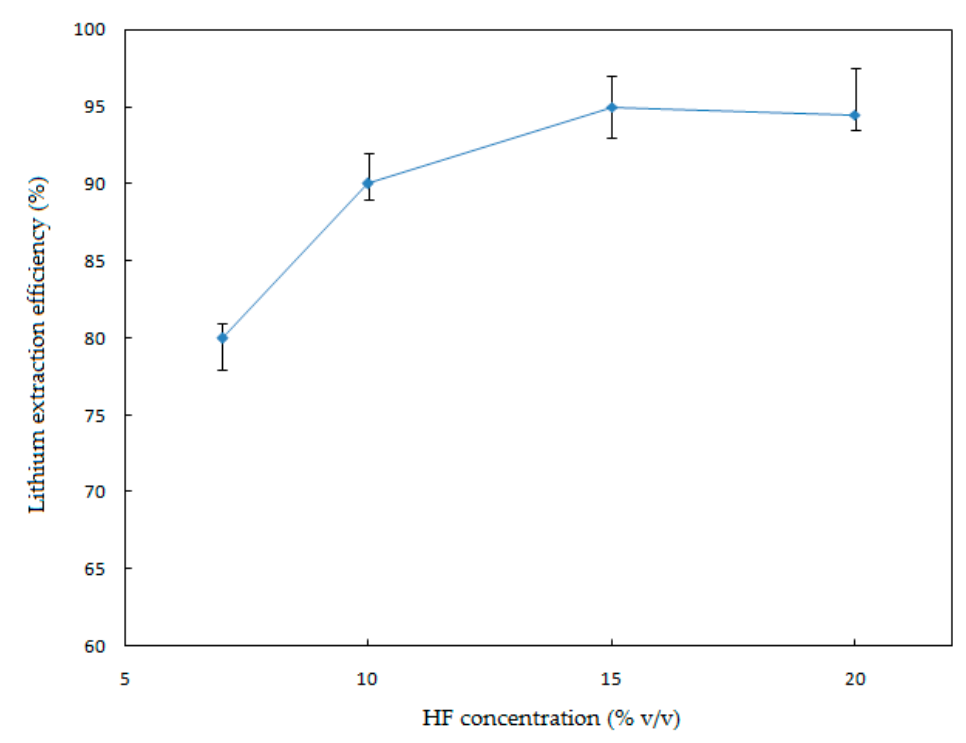

Figure 5. Effect of HF concentration on the Li extraction efficiency.

Figure 5 illustrates that the HF concentration has a notorious effect on the leaching process. The extraction efficiency increased significantly when the HF concentration was increased from $7 \%$ to $20 \%(v / v)$. The maximum extraction value of $\mathrm{Li}(95 \%)$ was achieved by working with $\mathrm{HF} 15 \%(v / v)$. Above 15\% $(v / v)$ of $\mathrm{HF}$, the Li extraction percentage decreased, since high concentrations of HF produce a precipitation of $\mathrm{Li}$ alkali fluorides (e.g., $\mathrm{Li}_{3} \mathrm{Na}_{3} \mathrm{Al}_{2} \mathrm{~F}_{12}$ ) [17].

\subsubsection{Characterization of the Residue}

Figure 6 presents the diffractograms of the leaching residues obtained at 123 and $160{ }^{\circ} \mathrm{C}$ with extractions of $90 \%$ and $95 \%$ of $\mathrm{Li}$, respectively, under the following experimental conditions: $\mathrm{HF}$, $7 \%(v / v)$ and time, $120 \mathrm{~min}$.

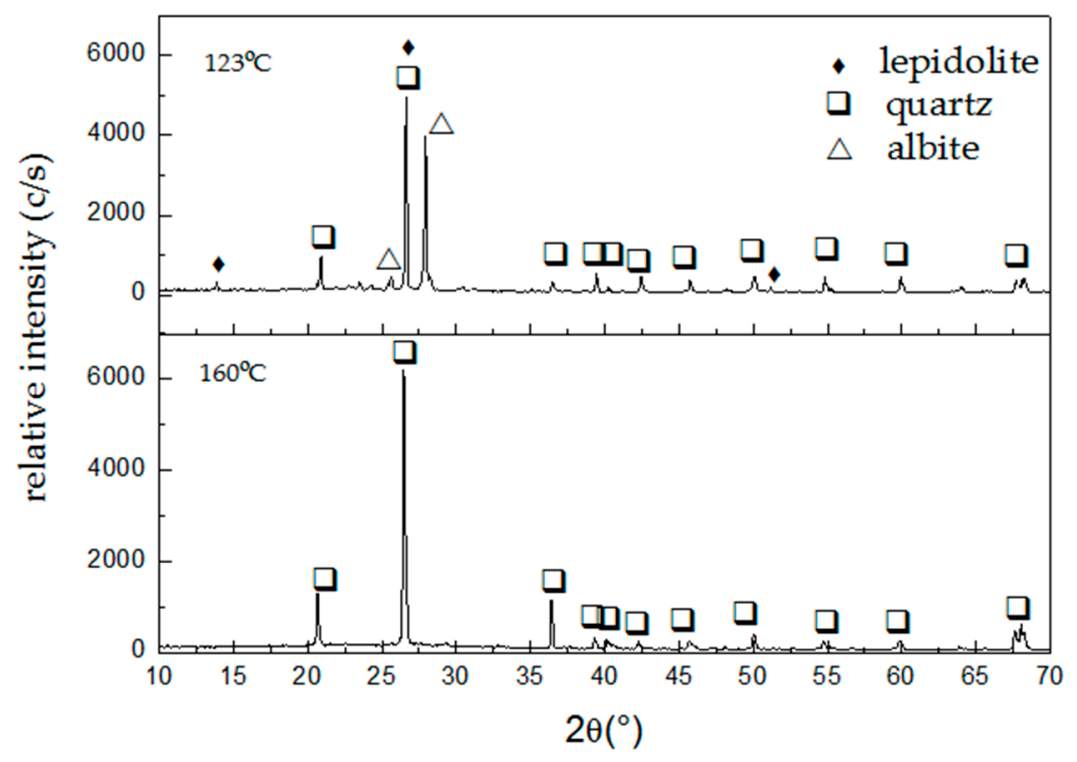

Figure 6. XRD patterns of the leaching residue obtained at 123 and $160{ }^{\circ} \mathrm{C}$. 
From Figure 6 it can be inferred that the dissolution of the lepidolite present in the ore occurs, and even more, it enhances the intensity of the diffraction lines of albite and quartz. This indicates that, working at $123^{\circ} \mathrm{C}$, the dissolution reaction is preferential for lepidolite. Meanwhile, the dissolution of lepidolite and albite is achieved at $160^{\circ} \mathrm{C}$, leaving quartz in the leaching residue.

\subsection{Recovery of $\mathrm{Si}$, Al and $\mathrm{Li}$}

\subsubsection{Recovery of Silicon as $\mathrm{K}_{2} \mathrm{SiF}_{6}$}

The leach liquor obtained after the first filtration was treated with $\mathrm{KOH}$ to precipitate the residual $\mathrm{Si}$ according to Equation (2). The amount of $\mathrm{KOH}$ used was equal to the stoichiometric value calculated from Equation (2). The result of the XRD characterization of the obtained solid is shown in Figure 7.

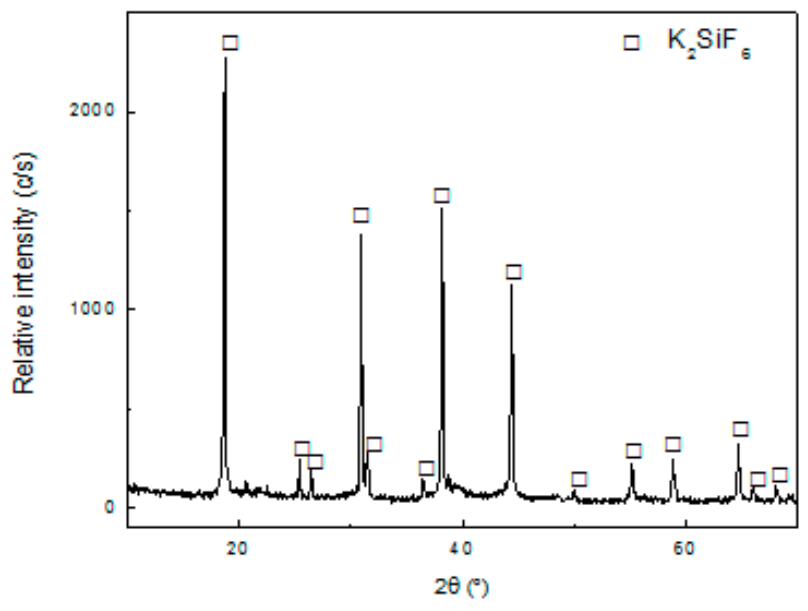

Figure 7. XRD pattern of the precipitated $\mathrm{K}_{2} \mathrm{SiF}_{6}$.

Figure 7 shows the appearance of diffraction lines that correspond to the structure of $\mathrm{K}_{2} \mathrm{SiF}_{6}$ (JCPDS 7-217), which is in agreement with the proposed Equation (2). By gravimetry, it was determined that the recovery of $\mathrm{Si}$ was $93 \%$.

The $\mathrm{K}_{2} \mathrm{SiF}_{6}$ precipitate was analyzed by microanalysis EDS and XRF to determine the purity of the precipitate. Table 2 shows the purity of the compound.

Table 2. Purity of $\mathrm{K}_{2} \mathrm{SiF}_{6}$.

\begin{tabular}{cccccccccc}
\hline \multirow{2}{*}{ Purity of $\mathrm{K}_{\mathbf{2}} \mathrm{SiF}_{\mathbf{6}}(\mathbf{w t} \%)$} & \multicolumn{8}{c}{ Elemental Composition (wt \%) } \\
\cline { 2 - 10 } & $\mathbf{S i}$ & $\mathbf{K}$ & $\mathbf{F}$ & $\mathbf{N a}$ & $\mathbf{A l}$ & $\mathbf{O}$ & $\mathbf{M n}$ & $\mathbf{F e}$ & Others \\
\hline 98.8 & 16.9 & 35.1 & 46.8 & - & 0.2 & - & - & 0.2 & 0.8 \\
\hline
\end{tabular}

The results obtained from Figure 7 and Table 2 indicate that the precipitation reaction was highly selective to $\mathrm{Si}$, seeing that there was no formation of any $\mathrm{Al}$ and $\mathrm{Li}$ compound.

\subsubsection{Recovery of Aluminum as $\mathrm{Na}_{3} \mathrm{AlF}_{6}$}

To precipitate $\mathrm{Al}$ as $\mathrm{Na}_{3} \mathrm{AlF}_{6}$, the liquor obtained after the recovery of $\mathrm{Si}$ was treated with $\mathrm{NaOH}$ according to Equation (3) (Rosales et al., $[16,17])$. The amount of $\mathrm{NaOH}$ used was equal to the stoichiometric value calculated from Equation (3). After the addition of $\mathrm{NaOH}$, the appearance of a white precipitate corresponding to $\mathrm{Na}_{3} \mathrm{AlF}_{6}$ was observed. The solid was filtered and dried for characterization.

Figure 8 shows the diffractogram of the solid obtained after the addition of $\mathrm{NaOH}$. 


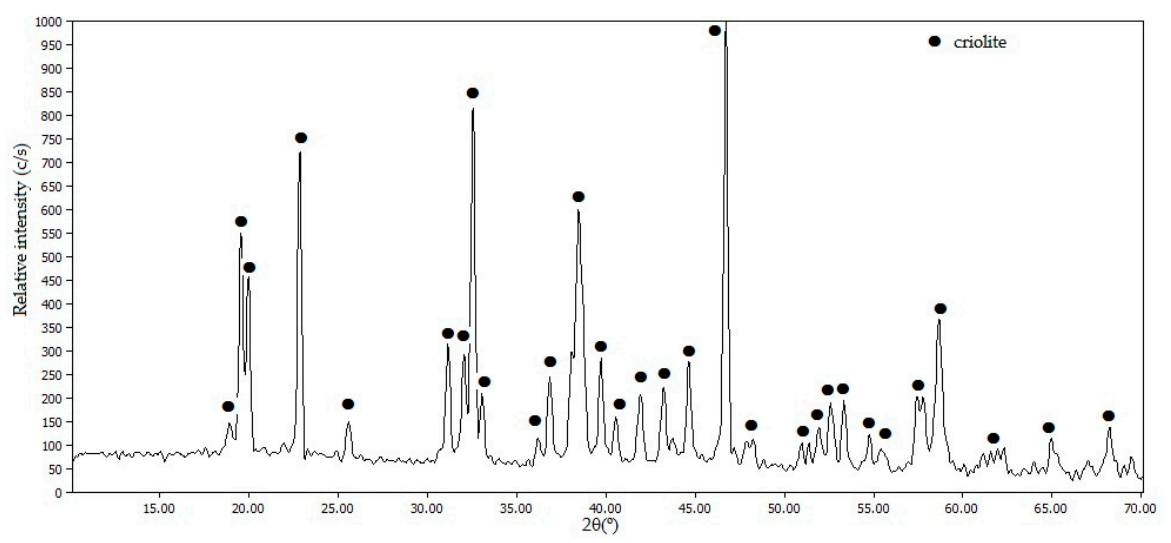

Figure 8. XRD pattern of the precipitated $\mathrm{Na}_{3} \mathrm{AlF}_{6}$.

The diffractogram in Figure 8 indicates that the formation of solid $\mathrm{Na}_{3} \mathrm{AlF}_{6}$ has taken place according to Equation (3), without other phases detected as impurities.

Table 3 shows the purity of the compound $\mathrm{Na}_{3} \mathrm{AlF}_{6}$, obtained by microanalysis EDS and XRF.

Table 3. Purity of $\mathrm{Na}_{3} \mathrm{AlF}_{6}$.

\begin{tabular}{cccccccccc}
\hline \multirow{2}{*}{ Purity of $\mathrm{Na}_{3} \mathrm{AlF}_{\mathbf{6}}(\mathbf{w t} \%)$} & \multicolumn{10}{c}{ Elemental Composition $(\mathbf{w t} \%)$} \\
\cline { 2 - 10 } & $\mathrm{Al}$ & $\mathbf{N a}$ & $\mathrm{F}$ & $\mathrm{K}$ & $\mathrm{Si}$ & $\mathrm{O}$ & $\mathbf{M n}$ & $\mathrm{Fe}$ & Others \\
\hline 89.5 & 15.7 & 34.6 & 39.2 & 1.8 & 2.5 & 4.2 & - & 0.21 & 1.79 \\
\hline
\end{tabular}

The appearence of $\mathrm{Na}_{2} \mathrm{SiF}_{6}$ in the diffractogram of Figure 8 is not observed, but the presence of $\mathrm{Si}$ (2.5\%) by EDS analysis is detected. This indicates that the $\mathrm{Si}$, which was not recovered in the previous step, was precipitated as $\mathrm{Na}_{2} \mathrm{SiF}_{6}$ in amounts below the detection limit of XRD. For further purification the solid can be washed with solutions at different $\mathrm{pH}$ values [20]. The achieved recovery percentage of $\mathrm{Al}$ was $95 \%$.

\subsubsection{Recovery of Lithium as $\mathrm{LiF}$}

The liquor obtained after the recovery of $\mathrm{Al}$ and $\mathrm{Si}$ was evaporated $\left(\right.$ at $75^{\circ} \mathrm{C}$ ) until the appearance of a gelatinous white precipitate that corresponded to $\mathrm{LiF}$ [23]. The obtained solid was washed and dried at $75^{\circ} \mathrm{C}$ for further characterization. The total lithium precipitation, obtained by gravimetric analisys, was about $92 \%$. Figures 9 and 10 show the diffractogram and the SEM micrograph of the obtained LiF, respectively.

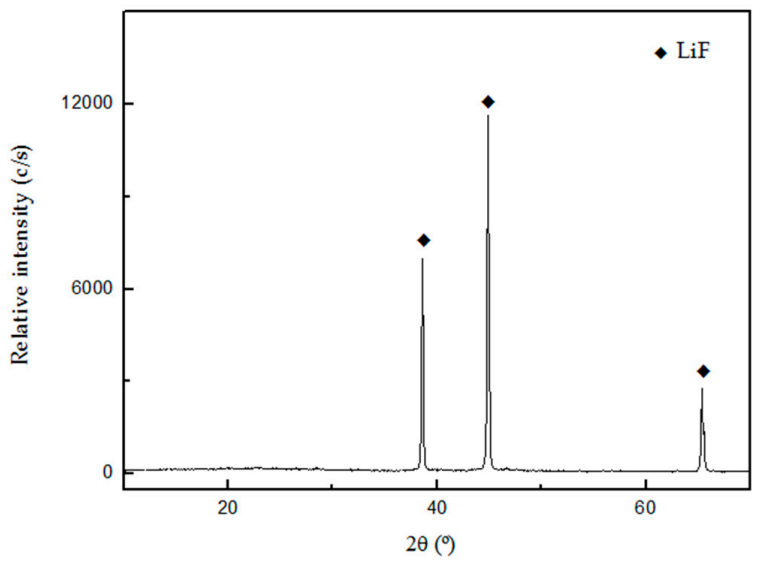

Figure 9. Diffractogram of the precipitated LiF. 


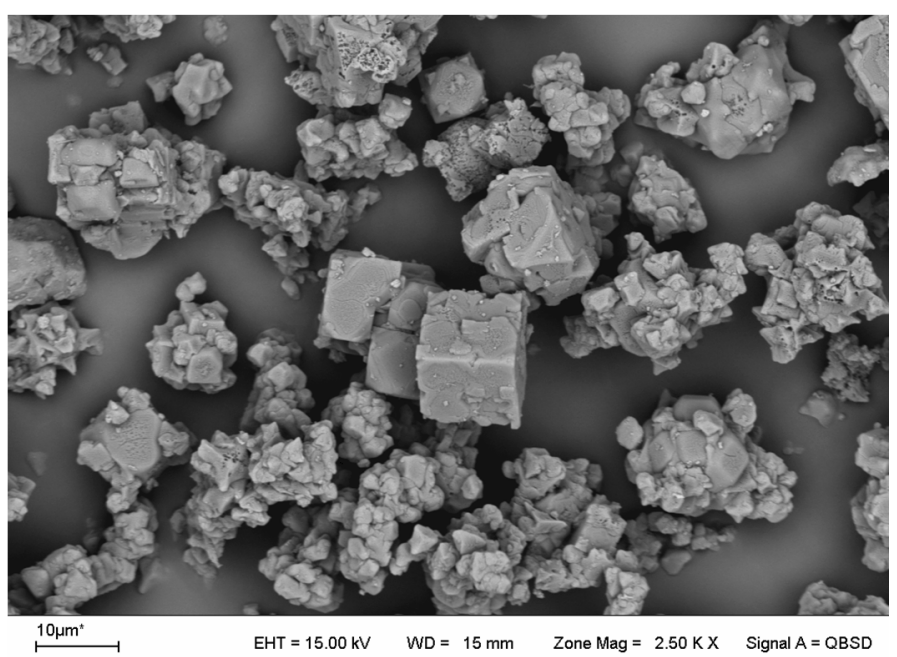

Figure 10. SEM micrograph of the precipitated LiF.

Figure 9 shows that the compound $\mathrm{LiF}$ was obtained without other phases as impurities. Frontino et al. (2008), obtained a similar diffractogram for the precipitation of LiF from spent Li-ion batteries [23].

In Figure 10 it can be seen that the LiF particles have a well-defined crystal structure and coincided with the cubic shape of $\mathrm{LiF}$ particles found in the literature.

The resulting LiF was analyzed by AAS and EDS to determine the concentration of major impurities in the sample. The results are presented in Table 4.

Table 4. Purity of LiF.

\begin{tabular}{cccccccc}
\hline \multirow{2}{*}{ Purity of LiF (wt \%) } & \multicolumn{7}{c}{ Elemental Composition (wt \%) } \\
\cline { 2 - 8 } & $\mathbf{L i}$ & $\mathbf{F}$ & $\mathbf{N a}$ & $\mathbf{K}$ & $\mathbf{C a}$ & $\mathbf{M n}$ & Others \\
\hline 99.1 & 26.7 & 72.5 & 0.08 & 0.05 & 0.02 & 0.03 & 0.59 \\
\hline
\end{tabular}

Table 4 indicates that the purity of the $\mathrm{LiF}$ precipitated was $99.1 \%$.

\section{Conclusions}

In summary, a process that includes leaching with $\mathrm{HF}$ was employed to extract $\mathrm{Li}, \mathrm{Al}$ and $\mathrm{Si}$ from lepidolite. The experimental results indicate that the optimal conditions to achieve a $\mathrm{Li}$ extraction higher than $90 \%$ are: solid-liquid ratio, $1.82 \%(w / v)$; temperature, $123{ }^{\circ} \mathrm{C}$; HF concentration, $7 \%(v / v)$; stirring speed, $330 \mathrm{rpm}$; and reaction time, $120 \mathrm{~min}$. The compounds $\mathrm{K}_{2} \mathrm{SiF}_{6}$ and $\mathrm{Na}_{3} \mathrm{AlF}_{6}$ can be obtained as subproducts of the process, with a recovery of $93 \%$ and $95 \%$, respectively. The Li dissolved can be separated by chemical precipitation as $\mathrm{LiF}$, with a recovery value of $92 \%$ and a purity of $99.1 \%$. Furthermore, $\mathrm{Al}$ and $\mathrm{Si}$ are recovered as valuable subproducts, diminishing the generation of residues during the process. The results of the current work can provide a simple, economic and effective way to recover Li from lepidolite.

Acknowledgments: The financial support from the Universidad Nacional de Cuyo, Secretaría de Ciencia, Técnica y Posgrado, is gratefully acknowledged. Two anonymous referees provided constructive and helpful reviews, corrections and comments. Many thanks are due to the editorial staff of Minerals.

Author Contributions: Gustavo D. Rosales, Eliana G. Pinna, Daniela S. Suarez and Mario H. Rodriguez conceived and designed the experiments; Gustavo D. Rosales, Eliana G. Pinna and Mario H. Rodriguez performed the experiments and analyzed the data; Mario H. Rodriguez contributed reagents, materials and analysis tools; Gustavo D. Rosales, Eliana G. Pinna, Daniel S. Suarez and Mario H. Rodriguez wrote the paper.

Conflicts of Interest: The authors declare no conflict of interest. 


\section{References}

1. Garret, D.E. Part 1-Lithium. In Handbook of Lithium and Natural Calcium Chloride; Elsevier Ltd.: London, UK, 2004.

2. Habashi, F. Alkali Metals_Lithium. In Handbook of Extractive Metallurgy; Wiley-VCH: Weinheim, Germany, 1997; Volume IV.

3. Das, B.; Pohl, A.; Chakravadhanula, V.S.K.; Kübel, C.; Fichtner, M. LiF/Fe $/ \mathrm{V}_{2} \mathrm{O}_{5}$ nanocomposite as high capacity cathode for lithium ion batteries. J. Power Sources 2014, 267, 203-211. [CrossRef]

4. Tressaud, A. Functionalized Inorganic Fluorides Synthesis: Characterization and Properties of Nanostructured Solids; John Wiley \& Sons: Hoboken, NJ, USA, 2010.

5. Fasel, D.; Tran, M.Q. Availability of lithium in the context of the future D-T fusion reactors. Fusion Eng. Des. 2005, 75-79, 1163-1168. [CrossRef]

6. $\quad$ Lovering, D.G. Molten Salt Technology; Plenum Press: New York, NY, USA, 1982.

7. Byrns, A.C. Production of Cryolite. U.S. Patent 2,994,582, 1 August 1961.

8. Galliski, M. La Provincia Pegmatítica Pampeana II: Tipología y distribución de sus distritos económicos. Rev. Asoc. Geol. Argent. 1994, 49, 99-112. (In Spanish)

9. Galliski, M. La Provincia Pegmatítica Pampeana II: Metalogénesis de sus distritos económicos. Rev. Asoc. Geol. Argent. 1994, 49, 113-122. (In Spanish)

10. Hien-Dinh, T.T.; Luong, V.T.; Gieré, R.; Tran, T. Extraction of lithium from lepidolite via iron sulphide roasting and water leaching. Hydrometallurgy 2015, 153, 154-159. [CrossRef]

11. Kuang, G.; Li, H.; Hu, S.; Jin, R.; Liu, S.; Guo, H. Recovery of aluminum and lithium from gypsum residue obtained in the process of lithium extraction from lepidolite. Hydrometallurgy 2015, 157, 214-218. [CrossRef]

12. Yan, Q.; Li, X.; Wang, Z.; Wu, X.; Wang, J.; Guo, H.; Hu, Q.; Peng, W. Extraction of lithium from lepidolite by sulfation roasting and water leaching. Int. J. Miner. Process. 2012, 110-111, 1-5. [CrossRef]

13. Yan, Q.; Li, X.; Yin, Z.; Wang, Z.; Guo, H.; Peng, W.; Hu, Q. A novel process for extracting lithium from lepidolite. Hydrometallurgy 2012, 121-124, 54-59. [CrossRef]

14. Yan, Q.; Li, X.; Wang, Z.; Wu, X.; Guo, H.; Hu, Q.; Peng, W.; Wang, J. Extraction of valuable metals from lepidolite. Hydrometallurgy 2012, 117-118, 116-118. [CrossRef]

15. Brumbaugh, R.; Fanus, W. Determination of lithium in spodumene by flame photometry. Anal. Chem. 1954, 26, 463-465. [CrossRef]

16. Rosales, G.; Ruiz, M.C.; Rodriguez, M. Alkaline metal fluorides synthesis as subproduct of $\beta$-spodumene leaching. Hydrometallurgy 2013, 139, 73-78. [CrossRef]

17. Rosales, G.; Ruiz, M.C.; Rodriguez, M.H. Novel process for the extraction of lithium from $\beta$-spodumene by leaching with HF. Hydrometallurgy 2014, 147-148, 1-6. [CrossRef]

18. Rosales, G.; Ruiz, M.C.; Rodriguez, M. Study of the extraction kinetics of lithium by leaching $\beta$-spodumene with hydrofluoric acid. Minerals 2016, 6, 98. [CrossRef]

19. Kumar, M.; Mankhand, T.R.; Murthy, D.S.R.; Mukhopadhyay, R.; Prasad, P.M. Refining of a low-grade molybdenite concentrate. Hydrometallurgy 2006, 86, 56-62. [CrossRef]

20. Kumar, M.; Nani, M.; Mankhand, T.; Pandey, B. Precipitation of sodium silicofluoride $\left(\mathrm{Na}_{2} \mathrm{SiF}_{6}\right)$ and cryolite $\left(\mathrm{Na}_{3} \mathrm{AlF}_{6}\right)$ from $\mathrm{HF} / \mathrm{HCl}$ leach liquors of alumino-silicates. Hydrometallurgy 2010, 104, 304-307. [CrossRef]

21. Lisbona, D.F.; Steel, K.M. Recovery of fluoride values from spent pot-lining: Precipitation of an aluminum hydroxyfluoride hydrate product. Sep. Purif. Technol. 2008, 61, 182-192. [CrossRef]

22. Burriel Martí, F.; Lucena Conde, F.; Arribas Jimeno, S. Química Analítica Cualitativa; Parainfo: Madrid, Spain, 1998. (In Spanish)

23. Frontino, P.J.; Giovanini, N.; Afonso, J.C. Recovery of valuable elements from spent Li-batteries. J. Hazard. Mater. 2008, 150, 843-849.

(C) 2017 by the authors. Licensee MDPI, Basel, Switzerland. This article is an open access article distributed under the terms and conditions of the Creative Commons Attribution (CC BY) license (http:/ / creativecommons.org/licenses/by/4.0/). 